\title{
A dual isotopic approach using radioactive phosphorus and the isotopic composition of oxygen associated to phosphorus to understand plant reaction to a change in P nutrition
}

\author{
Verena Pfahler ${ }^{1,2^{*}} \mathbb{0}$, Federica Tamburini ${ }^{1}$, Stefano M. Bernasconi ${ }^{3}$ and Emmanuel Frossard ${ }^{1}$
}

\begin{abstract}
Background: Changing the phosphorus (P) nutrition leads to changes in plant metabolism. The aim of this study was to investigate how these changes are reflected in the distribution of ${ }^{33} \mathrm{P}$ and the isotopic composition of oxygen associated to $\mathrm{P}\left({ }^{18} \mathrm{O}_{\mathrm{p}}\right)$ in different plant parts of soybean (Glycine max $\mathrm{cv}$. Toliman). Two P pools were extracted sequentially with $0.3 \mathrm{M}$ trichloroacetic acid (TCA P) and $10 \mathrm{M}$ nitric acid $\left(\mathrm{HNO}_{3}\right.$; residual $\left.\mathrm{P}\right)$.

Results: The $\delta^{18} \mathrm{O}_{\mathrm{p}}$ of TCA P in the old leaves of the - P plants (23.8\%) significantly decreased compared to the $+\mathrm{P}$ plants $(27.4 \% 0)$. The ${ }^{33} \mathrm{P}$ data point to an enhanced mobilisation of $\mathrm{P}$ from residual $\mathrm{P}$ in the old leaves of the $-\mathrm{P}$ plants compared to the $+\mathrm{P}$ plants.

Conclusions: Omitting P for 10 days lead to a translocation of P from source to sink organs in soybeans. This was accompanied by a significant lowering of the $\delta^{18} \mathrm{O}_{\mathrm{p}}$ of TCA $\mathrm{P}$ in the source organs due to the enzymatic hydrolysis of organic P. Combining ${ }^{33} \mathrm{P}$ and $\delta^{18} \mathrm{O}_{\mathrm{p}}$ can provide useful insights in plant responses to P omission at an early stage.
\end{abstract}

Keywords: $\delta^{18} \mathrm{O}_{\mathrm{p}}$ of TCA P, ${ }^{33} \mathrm{P}$, Phosphorus, Radioisotopes, Soybeans, Stable isotopes

\section{Background}

Phosphorus $(\mathrm{P})$ is an essential nutrient for plants. It is taken up by the roots as phosphate and is translocated to the leaves and other plant parts through the xylem and phloem $[1,2]$. In plants with a high $P$ status, a large proportion (85-95\%) of phosphate in cells is stored in the vacuole (non-metabolic P), whereas only $5-15 \%$ are considered as metabolic P, i.e. P taking part in plant metabolism [3, 4]. When P supply becomes limiting for plant growth, $\mathrm{P}$ stored in the vacuole is mobilised and translocated from old leaves (source) to growing plant tissues (sinks) like developing leaves and fruits $[5,6]$.

\footnotetext{
*Correspondence: verena.pfahler@rothamsted.ac.uk

1 Department of Environmental Systems Science, ETH Zurich, Eschikon 33, 8315 Lindau, Switzerland

Full list of author information is available at the end of the article
}

Plant responses to a low P nutrition status also include replacement of phospholipids by sulfo- or galactolipids, the activation of acid phosphatase, a higher expression of high affinity $P$ transporters, and a decrease in nucleic acid concentration [7-11].

The use of ${ }^{32} \mathrm{P}$ and/or ${ }^{33} \mathrm{P}$ can elucidate $\mathrm{P}$ translocation from developed to developing leaves in plants $[1$, $3,12,13$. Before $P$ is translocated it needs to be mobilised, either from $P$ stored in the vacuole or via enzymatic hydrolysis of organic P compounds. The stable isotope composition of oxygen associated to phosphorus (noted thereafter $\delta^{18} \mathrm{O}_{\mathrm{P}}$ ) is altered by enzymatic processes and thus could provide information on these processes. Enzymes can exchange one to four oxygen $(\mathrm{O})$ atoms bound to $\mathrm{P}$ with $\mathrm{O}$ of ambient water [14-16]. The inorganic pyrophosphatase (inorganic PPase), an ubiquitous enzyme regulating the pyrophosphate level in cells, is 
responsible for a temperature dependent equilibrium between $\mathrm{O}$ in water and phosphate [17-19]. Also, other acid anhydride hydrolases involved in the transport of nutrients across membranes, could lead to equilibrium between $\mathrm{O}$ in water and in phosphate [20]. Enzymes, which catalyse the hydrolysis of organic $\mathrm{P}$ compounds such as acid or alkaline phosphatase, release phosphate with a different $\delta^{18} \mathrm{O}_{\mathrm{P}}$ compared to the original organic $\mathrm{P}$ compound due to isotopic fractionation [21,22]. Alkaline and acid phosphatases, 5' -nucleotidase, and deoxyribonuclease 1 preferentially incorporate ${ }^{16} \mathrm{O}$ from water into phosphate, resulting in the release of phosphate depleted in ${ }^{18} \mathrm{O}$ compared to the original organic $\mathrm{P}$ compound $[16$, $21,22]$.

We previously investigated the ${ }^{18} \mathrm{O}$ enrichment of trichloroacetic acid soluble reactive P (TCA P; mainly phosphate [23]) extracted from soybean leaves (Glycine max cv. Toliman) grown under $\mathrm{P}$ sufficient conditions in the glasshouse. We found that the $\delta^{18} \mathrm{O}$ of leaf water was the main control of $\delta^{18} \mathrm{O}_{\mathrm{P}}$ of TCA P in soybean leaves under our experimental set-up [23].

We assess here the effects of stopping the P supply in the nutrient solution on the $\delta^{18} \mathrm{O}_{\mathrm{P}}$ of TCA P in different plant parts of previously well-fed soybean plants. We hypothesise that stopping $\mathrm{P}$ supply will lead to lower $\delta^{18} \mathrm{O}_{\mathrm{P}}$ of TCA $\mathrm{P}$ in source organs resulting from an increasing phosphatase activity caused by the interruption in P supply. This is tested in a single experiment in which $\mathrm{P}$ fluxes between plant organs are measured with ${ }^{33} \mathrm{P}$ tracing while the effect of phosphatase is analysed through its effect on the $\delta^{18} \mathrm{O}_{\mathrm{p}}$ of plant $\mathrm{P}$. To our knowledge, this is the first time that such a dual isotopic approach is conducted to assess plant response to changing $\mathrm{P}$ nutritional status.

\section{Methods}

\section{Experimental set up}

Soybean (Glycine max cv. Toliman) was grown under controlled conditions in a glasshouse in hydroponic cultures. Soybean seeds were surface-sterilized as described by Kremer et al. [24] and germinated in sand (size $0.7-1.2 \mathrm{~mm}$ ) saturated with ultrapure water $\left(\mathrm{ddH}_{2} \mathrm{O}\right) .8$ days after seeding (DAS; stage V2, [25]), 250 plants were transferred into a hydroponic set up. 7 days later (15 DAS; stage V3), 88 soybean plants were transferred into eleven non-transparent plastics pots (size $300 \mathrm{~mm} \times 200 \mathrm{~mm} \times 220 \mathrm{~mm}$ ) containing $8 \mathrm{~L}$ nutrient solution (eight plants per pot). From 8 to 15 DAS, the plants were supplied with a modified Hoagland nutri-

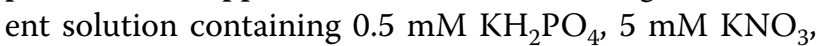
$5 \mathrm{mM} \mathrm{Ca}\left(\mathrm{NO}_{3}\right)_{2}, 2 \mathrm{mM} \mathrm{MgSO}, 0.1 \mathrm{mM}$ Fe chelate, $0.05 \mathrm{mM} \mathrm{KCl}, 0.025 \mathrm{mM} \mathrm{H}_{3} \mathrm{BO}_{3}, 0.002 \mathrm{mM} \mathrm{MnSO}$, $0.002 \mathrm{mM} \mathrm{ZnSO}_{4}, 0.0005 \mathrm{mM} \mathrm{CuSO}_{4}$, and $0.0005 \mathrm{mM}$
$\mathrm{Na}_{2} \mathrm{MoO}_{4}$. The $\mathrm{KH}_{2} \mathrm{PO}_{4}$ used for the preparation of the nutrient solution had a $\delta^{18} \mathrm{O}_{\mathrm{p}}$ of $12.4 \%$ and the water in the nutrient solution had a $\delta^{18} \mathrm{O}$ of $-10.2 \%$. The nutrient solution was changed regularly to reduce microbial growth and ensure optimal growth conditions for the plants. The 88 soybean plants were distributed in 11 pots representing three treatments: control, $+\mathrm{P}$, and $-\mathrm{P}$ plants. Three replicates were used for the control, while the $+\mathrm{P}$ and $-\mathrm{P}$ treatments were replicated 4 times, with eight plants per pot.

At 15 DAS, $10 \mathrm{~mL}$ of a stock solution was prepared containing $1 \mathrm{~mL}$ of carrier-free ${ }^{33} \mathrm{P}_{-}-\mathrm{PO}_{4}$ and $9 \mathrm{~mL}$ of nutrient solution. The control plants received $0.6 \mathrm{~mL}$ of this ${ }^{33} \mathrm{P}$-containing solution per pot (equivalent to $20 \mathrm{MBq}$ per pot), while the $+\mathrm{P}$ (sufficient amount of $\mathrm{P}$ supplied throughout the experiment) and $-\mathrm{P}$ (no P supplied for 10 days) plants received $0.9 \mathrm{~mL}$ per pot (equivalent to $30 \mathrm{MBq}$ per pot). The plants remained in the labelled nutrient solution for 8 days (23 DAS; stage V5). After this period the plants in three pots (referred to as "control") were harvested and the remaining eight pots were divided into two groups (four pots per group). The $+\mathrm{P}$ plants received the non-labelled nutrient solution with $0.5 \mathrm{mM} \mathrm{KH}_{2} \mathrm{PO}_{4}$; while the $-\mathrm{P}$ plants received a $\mathrm{P}$-free nutrient solution. Before the transfer of the plants to the new nutrient solution, the roots were washed twice with P-free nutrient solution to avoid any carry-over of ${ }^{31} \mathrm{P}$ and ${ }^{33} \mathrm{P}$ into the new nutrient solution. After 10 days (33 DAS; stage V7/8) the $+\mathrm{P}$ and $-\mathrm{P}$ plants were harvested. In the middle of this period (28 DAS) $2 \mathrm{~L}$ P-free nutrient solution was added to each pot of the $-\mathrm{P}$ plants while $2 \mathrm{~L}$ nutrient solution containing $0.5 \mathrm{mM} \mathrm{KH}_{2} \mathrm{PO}_{4}$ were added to each pot of the $+\mathrm{P}$ plants.

Relative air humidity in the glasshouse ranged between 44 and $61 \%$, with a mean of $58 \%$. The air temperature ranged between 17 and $23{ }^{\circ} \mathrm{C}$, with a mean of $21{ }^{\circ} \mathrm{C}$. The plants were illuminated with 35 klux for $16 \mathrm{~h}$ per day. Leaf temperature of the trifoliate leaves was measured at the time of the harvest using a laser thermometer (Messtechnik Schaffhausen GmbH, Switzerland). For all treatments, the leaf temperature ranged between 19 and $22^{\circ} \mathrm{C}$, in average $20^{\circ} \mathrm{C}$, for the old leaves and between 20 and $24^{\circ} \mathrm{C}$, with an average of $22^{\circ} \mathrm{C}$ for the new leaves.

\section{Harvest}

All plants were harvested approximately at the same time of the day (ca. 11:00) and within $30 \mathrm{~min}$, to reduce the effect of sampling time on the $\delta^{18} \mathrm{O}_{\mathrm{P}}$ of TCA P, which can be up to $7 \%$ [26].

The plants were separated into five parts: roots, stems, old, new, and senescent leaves. Middle veins of the old and new leaves are included in the plant part "stems", as, like the stems, they contain water with the $\delta^{18} \mathrm{O}$ of the 
source water [27]. The part "old leaves" includes the trifoliate leaves, which were already fully developed when the control plants were harvested. The part "new leaves" includes trifoliate leaves, which were not fully developed when the control plants were harvested, and for the $+\mathrm{P}$ and $-\mathrm{P}$ plants, also those that developed after the harvest of the control plants. The plant samples were put at $-20{ }^{\circ} \mathrm{C}$ directly after sampling. The senescent unifoliate leaves were collected and dried at $45^{\circ} \mathrm{C}$ for 2 days before milling to a fine powder $(<2 \mathrm{~mm})$. The unifoliate leaves were only used to determine the recovery of ${ }^{33} \mathrm{P}$ taken up by the plants from the nutrient solution and the distribution of ${ }^{33} \mathrm{P}$ in the plants.

\section{Extraction of plant material}

Two different $\mathrm{P}$ pools were sequentially extracted from each plant part, yielding in total eight compartments. The first step of the sequential extraction with TCA is targeting mainly inorganic phosphate [28], but may also extract some labile organic $\mathrm{P}$ compounds (such as glucose6-phosphate) that can be hydrolysed during the colorimetric essay [29]. For this reason, this fraction is referred to as TCA-soluble reactive $\mathrm{P}$ (TCA P). Two grams of frozen plant material were weighed into $60-\mathrm{mL}$ plastic bottles and $40 \mathrm{~mL}$ of $0.3 \mathrm{M}$ TCA were added. After homogenising with a Polytron ${ }^{\circledR}$ (Kinematica AG, Luzern, Switzerland), the plant material was extracted for $1 \mathrm{~h}$ at $4{ }^{\circ} \mathrm{C}$. The extracts were vacuum filtered using GF/F (pore size $0.7 \mu \mathrm{m}$; Whatman Internal Ltd.) filters before further processing for $\delta^{18} \mathrm{O}_{\mathrm{p}}$ measurements.

The plant material remaining after the extraction with TCA was extracted with $10 \mathrm{M} \mathrm{HNO}_{3}$ following the protocol described by [30] and modified by [23]. The extraction with $10 \mathrm{M} \mathrm{HNO}_{3}$ targets stable organic $\mathrm{P}$ compounds, such as phospholipids and DNA, and is referred to as residual $\mathrm{P}$. The material was transferred into $50-\mathrm{mL}$ centrifuge tubes and $40 \mathrm{~mL}$ of $10 \mathrm{M} \mathrm{HNO}_{3}$ were added. The samples were put into a water bath at $50{ }^{\circ} \mathrm{C}$ and extracted overnight. On the following day, the extracts were transferred into $100-\mathrm{mL}$ Erlenmeyer flasks, put on stirring plates and $0.3 \mathrm{M}$ potassium permanganate $\left(\mathrm{KMnO}_{4}\right)$ was added drop wise until a brownish precipitate formed. On the next day, 0.1 M sodium nitrite $\left(\mathrm{NaNO}_{2}\right)$ was added until the brownish precipitate dissolved. The extracts were filtered through GF/F filters before further processing.

Additionally, total $\mathrm{P}$ was extracted from the senescent unifoliate leaves via ashing. $0.25 \mathrm{~g}$ of dried and milled plant powder was weighed into a porcelain crucible and ashed in an oven for $6 \mathrm{~h}$ at $550{ }^{\circ} \mathrm{C}$. Three millilitres of 14.3 $\mathrm{M} \mathrm{HNO}_{3}$ were added and the extract was diluted and filtered through a $0.2 \mu \mathrm{m}$ filter before determining the P concentration.
The concentration of $\mathrm{P}$ in the $0.3 \mathrm{M}$ TCA and $10 \mathrm{M}$ $\mathrm{HNO}_{3}$ extracts and in the total $\mathrm{P}$ extract of the unifoliate leaves was determined colorimetrically as described by [31].

\section{Measurement of the ${ }^{33} \mathrm{P}$ activity}

The activity of ${ }^{33} \mathrm{P}$ in each plant extract and in the nutrient solutions was measured with a liquid scintillation counter (TRI-CARB 2500 TR, liquid scintillation analyser, Packard Instruments, USA). Half a millilitre of each extract was mixed with $5 \mathrm{~mL}$ of liquid scintillation counting cocktail and measured for ten minutes. Two types of liquid scintillation counting cocktails were used, Ultima Gold for the 0.3 M TCA extracts and the nutrient solutions and Ultima Gold $\mathrm{AB}$ for the $10 \mathrm{M} \mathrm{HNO}_{3}$ and total $P$ extracts (Perkin Elmer, USA). All activities were corrected for the radioactive decay and calculated back to the start of the labelling period (15 DAS).

\section{Purification of extracts and precipitation of silver phosphate for the $\delta^{18} O_{p}$ measurements}

Purification of the $0.3 \mathrm{M}$ TCA extracts and precipitation of silver phosphate $\left(\mathrm{Ag}_{3} \mathrm{PO}_{4}\right)$ followed the protocol described by [32]. One millilitre of $17.8 \mathrm{M} \mathrm{H}_{2} \mathrm{SO}_{4}$ was added during the ammonium phospho-molybdate (APM) step to facilitate the precipitation of APM. The extraction with $10 \mathrm{M} \mathrm{HNO}_{3}$ is not suitable for the determination of the $\delta^{18} \mathrm{O}_{\mathrm{p}}$.

\section{Determination of $\delta^{18} \mathrm{O}$ of phosphate and water}

The $\delta^{18} \mathrm{O}$ of water used for the nutrient solution was determined with the $\mathrm{CO}_{2}$ equilibration method [33]. For each sample, $0.2 \mathrm{~mL}$ were pipetted into a vacutainer, closed tightly, and flushed with a gas mixture of $0.3 \%$ $\mathrm{CO}_{2}$ in helium (He). After an equilibration time of $18 \mathrm{~h}$ at room temperature, the samples were measured with a gas bench device (Gas Bench II; Thermo Fisher Scientific Inc., Waltham, MA, USA) coupled to an isotope ratio mass spectrometer (Delta V Plus; Thermo Fisher Scientific $\left.{ }^{\circledR}\right)$. The system was calibrated with the international standards VSMOW (Vienna Standard Mean Ocean Water; $\delta^{18} \mathrm{O}=0 \%$ ), SLAP (Standard Light Antarctic Precipitation; $\delta^{18} \mathrm{O}=-55.5 \%$ VSMOW) and GISP (Greenland Ice Sheet Precipitation; $\delta^{18} \mathrm{O}=-24.8 \%$ VSMOW). The analytical error was lower than $\pm 0.06 \%$.

The $\mathrm{Ag}_{3} \mathrm{PO}_{4}$ samples were measured in triplicates by a thermal conversion elemental analyser (vario PYRO cube; Elementar, Germany) coupled to an isotope ratio mass spectrometer (IRMS; Isoprime, UK). Results were calibrated against an internal $\mathrm{Ag}_{3} \mathrm{PO}_{4}$ standard (Acros Organics, Geel, Belgium; $\delta^{18} \mathrm{O}=14.2 \%$ VSMOW) and two benzoic acid standards distributed by the International Atomic Energy Agency (IAEA) in Vienna (IAEA 
601: $\delta^{18} \mathrm{O}=23.1 \%$ and IAEA 602: $\delta^{18} \mathrm{O}=71.3 \%$ VSMOW) [34]. Each run included $82 \mathrm{Ag}_{3} \mathrm{PO}_{4}$ samples, 16 samples of the $\mathrm{Ag}_{3} \mathrm{PO}_{4}$ standard, and eight samples of each benzoic acid standard. Analytical error calculated on replicate analyses of standards was lower than $\pm 0.4 \%$.

All oxygen isotope compositions are reported in the conventional delta notation with respect to VSMOW:

$\delta^{18} \mathrm{O}=1000 *\left(\frac{R_{\text {sample }}}{R_{\text {standard }}}-1\right)$,

where $R$ is the ratio ${ }^{18} \mathrm{O} /{ }^{16} \mathrm{O}$ in the sample and standard, respectively.

\section{Calculations and statistical analysis}

${ }^{33} \mathrm{P}$ uptake and recovery in the plants

The amount of ${ }^{33} \mathrm{P}$ taken up by the plants during the experiment was calculated by subtracting the activity of ${ }^{33} \mathrm{P}$ (MBq per pot) remaining in the nutrient solution before it was exchanged (23 DAS) from the activity of ${ }^{33} \mathrm{P}$ (MBq per pot) in the fresh nutrient solution at the start of the labelling period (15 DAS).

The total activity of ${ }^{33} \mathrm{P}$ in the plants per pot was calculated by Eq. 2:

${ }^{33} P_{\text {plant }}=\sum_{k=1}^{4}\left(T C A^{33} P+\text { residual }^{33} P\right)_{k}+{ }^{33} P_{\text {ashed }}$

where $k$ are the different plant parts and $T C A{ }^{33} P$, residual ${ }^{33} \mathrm{P}$, and ${ }^{33} \mathrm{P}_{\text {ashed }}$ represents the total activity of ${ }^{33} \mathrm{P}$ in the TCA P pool, residual P, and in the total $\mathrm{P}$ of the unifoliate leaves, respectively. The recovery of ${ }^{33} \mathrm{P}$ in the plants was calculated by dividing the total activity of ${ }^{33} \mathrm{P}$ in the plants per pot (Eq. 2) by the activity of ${ }^{33} \mathrm{P}$ taken up by the plants during the labelling period.

\section{Phosphorus derived from the labelling and non-labelling period}

The amount of $\mathrm{P}$ taken up during the labelling period can be calculated using Eq. 3:

$$
x=\frac{y}{S A_{\text {nut sol }}},
$$

where $x$ is the amount of $\mathrm{P}$ derived from the labelling period in $\mathrm{mg}$ per compartment and pot, $y$ is the activity of ${ }^{33} \mathrm{P}$ in the compartment in $\mathrm{kBq}$ per pot, and $S A_{n u t}$ ${ }_{s o l}$ is the specific activity of the $\mathrm{P}$ in the nutrient solution, which was taken up during the labelling period in $\mathrm{kBq} \mathrm{mg}^{-1} \mathrm{P}$.

The amount of $\mathrm{P}$ derived from other sources (that is, before and after the labelling period) in mg per compartment and pot can be calculated from:

$$
z=P_{\text {tot }}-x,
$$

where $z$ is the amount of $\mathrm{P}$ derived from before and after the labelling period in mg per compartment and pot, $P_{\text {tot }}$ is the total amount of $\mathrm{P}$ in a compartment in $\mathrm{mg}$ per pot, and $x$ is the amount of $\mathrm{P}$ derived from the labelling period in mg per compartment and pot.

\section{Net gains and losses of phosphorus in the different compartments}

The amount of $\mathrm{P}$ in the different compartments of the control plants was used as a baseline to calculate net gains and losses (turnover) of $\mathrm{P}$ in the different compartments of the $-\mathrm{P}$ and $+\mathrm{P}$. The turnover of $\mathrm{P}$ derived from the labelling period in the different compartments in the $-\mathrm{P}$ and $+\mathrm{P}$ plants during the last 10 days of the experiment (23-33 DAS) were calculated using Eq. 5:

$$
\begin{aligned}
& \text { Turnover of } P \text { derived from the labelling period } \\
& \quad=x_{\text {control }}-x_{i}
\end{aligned}
$$

where $x_{\text {control }}$ is the amount of $\mathrm{P}$ taken up during the labelling period (mg P per compartment and pot) in the control plants and $x_{i}$ is the amount of $\mathrm{P}$ taken up during the labelling period (mg P per compartment per pot) in the $+\mathrm{P}$ or $-\mathrm{P}$ plants. If the result is positive, the respective compartment is defined as sink for $\mathrm{P}$ derived from the labelling period (net gain), if the result is negative, the respective compartment is defined as source for $\mathrm{P}$ derived from the labelling period (net loss).

If a compartment was a sink or a source of $\mathrm{P}$ derived from the non-labelling period, was calculated using Eq. 6:

Turnover of $P$ derived from the nonlabelling period

$$
=z_{\text {control }}-z_{i}
$$

where $z_{\text {control }}$ is the amount of $\mathrm{P}$ taken up during the non-labelling period (mg $\mathrm{P}$ per compartment and pot; 0-15 DAS) in the control plants and $z_{i}$ is the amount of $\mathrm{P}$ taken up during the non-labelling period (mg $\mathrm{P}$ per compartment and pot; $0-15$ and 23-33 DAS) in the $+\mathrm{P}$ or $-\mathrm{P}$ plants. If the result is positive, the respective compartment is defined as sink for $\mathrm{P}$ derived from the non-labelling period (net gain), if the result is negative, the respective compartment is defined as source for $\mathrm{P}$ derived from the non-labelling period (net loss).

\section{Estimation of the leaf water $\delta^{18} \mathrm{O}$}

The leaf water $\delta^{18} \mathrm{O}$ was estimated based on data from a previous experiment where we looked at the daily changes of the leaf water $\delta^{18} \mathrm{O}$ and the $\delta^{18} \mathrm{O}_{\mathrm{P}}$ of TCA P of fully developed trifoliated soybean leaves [26]. A linear regression using the relative air humidity $(\mathrm{rH})$ in \% in the glasshouse and the leaf temperature $\left(t_{\text {leaf }}\right)$ in ${ }^{\circ} \mathrm{C}$ as 
independent variable and the leaf water $\delta^{18} \mathrm{O}$ as dependent variable gave the following equation:

Leaf water $\delta^{18} \mathrm{O}=14.72-0.17 \cdot r H+0.12 \cdot t_{\text {leaf }}$,

Adjusted $\mathrm{R}^{2}=0.55, p$ value $<0.001$.

The equilibrium between oxygen in water and in phosphate was calculated using the rearranged equation by [17]:

$\delta^{18} \mathrm{O}_{\mathrm{P}}=-0.17 \cdot t_{\text {leaf }}+26.2+$ leaf water $\delta^{18} \mathrm{O}$

\section{Statistical analysis}

To determine the effect of each treatment, the means of the different parameters were compared by conducting a one-way analysis of variance (ANOVA) using the program $\mathrm{R}$ [35]. For the multiple comparisons of the means (+ P compared to $-\mathrm{P},+\mathrm{P}$ compared to control, and $-\mathrm{P}$ compared to control) a Tukey's HSD test, with a significance level $\alpha$ of 0.05 , was performed afterwards as post hoc test. To determine significant differences between the $\delta^{18} \mathrm{O}_{\mathrm{P}}$ of TCA $\mathrm{P}$ in different plant parts within the same treatment a one-way ANOVA with a subsequent Tukey's HSD ( $\alpha=0.05)$ was performed as post hoc test. Pooled standard deviations were calculated for $M_{\mathrm{d}}$, total amount of $\mathrm{P}$ per compartment, $\mathrm{P}$ in each compartment derived from the labelling or non-labelling period, and the $\delta^{18} \mathrm{O}_{\mathrm{P}}$ of TCA P.

\section{Results}

Uptake of water, ${ }^{31} \mathrm{P}$, and ${ }^{33} \mathrm{P}$ during the experiment

The total water uptake per pot during the experiment (15-23 DAS in case of the control and 15-33 DAS in case of the $+\mathrm{P}$ and $-\mathrm{P}$ plants) was $1 \mathrm{~L}$ for the control and $4 \mathrm{~L}$ for the $+\mathrm{P}$ and $-\mathrm{P}$ plants.

The net uptake of $\mathrm{P}$ during the experiment (15-23 DAS in case of the control; 15-33 DAS in case of the $+\mathrm{P}$ and - P plants) was $46 \mathrm{mg}, 145 \mathrm{mg}$, and $43 \mathrm{mg}$ as average per pot for the control, $+\mathrm{P}$, and $-\mathrm{P}$ plants, respectively. The average uptake of ${ }^{33} \mathrm{P}$ per pot was $8.5 \mathrm{MBq}$ per pot, 11.4 MBq per pot, and 12.1 MBq per pot for the control, $+\mathrm{P}$, and $-\mathrm{P}$ plants, respectively. 42,39 , and $41 \%$ of ${ }^{33} \mathrm{P}$ added in the nutrient solution was taken up by the control, $+\mathrm{P}$, and $-\mathrm{P}$ plants. A small amount of ${ }^{33} \mathrm{P}$ was found in the nutrient solution of the $+\mathrm{P}$ and $-\mathrm{P}$ plants at 33 DAS (Table 1).

\section{Biomass and phosphorus concentrations in the plants}

The average dry mass $\left(M_{\mathrm{d}}\right)$ of the plants per pot increased significantly from the control (22 $\mathrm{g} M_{\mathrm{d}}$ per pot) to the $+\mathrm{P}$ and $-\mathrm{P}$ plants (39 and $41 \mathrm{~g} M_{\mathrm{d}}$ per pot, respectively) (ANOVA; $p$ value $<0.02$ ). The difference in $M_{\mathrm{d}}$ per pot between $+\mathrm{P}$ and $-\mathrm{P}$ plants was not significant. The $M_{\mathrm{d}}$ of the old leaves did not change significantly between the control and the $+\mathrm{P}$ and $-\mathrm{P}$ plants (Table 2 ).

The total amount of $\mathrm{P}$ in the control, $+\mathrm{P}$, and $-\mathrm{P}$ plants was 67.2, 153.2, and $58.3 \mathrm{mg}$ respectively. Although the total amount of $\mathrm{P}$ in the $+\mathrm{P}$ plants was about three times higher compared to the $-\mathrm{P}$ plants, we did not observe any visible signs of $\mathrm{P}$ limitation in case of the $-\mathrm{P}$ plants. The amount of $\mathrm{P}$ in the different compartments is shown in Table 3.

We observed significant differences in the concentration of TCA P for all four parts between the $+\mathrm{P}$ and $-\mathrm{P}$ plants. The difference in the concentration of TCA $\mathrm{P}$ between the control and $-\mathrm{P}$ plants was also significant in the case of the roots and the old leaves (Fig. 1). Significant differences in the concentration of residual $\mathrm{P}$ were only observed in case of the stems.

\section{Distribution of ${ }^{33} \mathrm{P}$ in the different compartments}

The total activity of ${ }^{33} \mathrm{P}$ found in the plants per pot was 9.5, 12.4, and $11.9 \mathrm{MBq}$ for the control, $+\mathrm{P}$, and $-\mathrm{P}$ plants, respectively. Thus, around $100 \%$ of the ${ }^{33} \mathrm{P}$, which

Table 1 Phosphorus content ( $\mathrm{mg} \mathrm{P}$ ) and activity (MBq) in the nutrient solution at the beginning of the labelling period [8 L; 15 days after seeding (DAS)], remaining at the end of the labelling period ( 7 L; 23 DAS), in the new nutrient solution after the labelling period (8 L; 23 DAS), and at the end of the experiment (7 L; 33 DAS)

\begin{tabular}{|c|c|c|c|c|c|c|c|c|}
\hline & \multicolumn{2}{|c|}{ Start (15 DAS) } & \multicolumn{2}{|c|}{ End of labelling (23 DAS) } & \multicolumn{2}{|c|}{ New nutrient solution (23 DAS) } & \multicolumn{2}{|c|}{$\begin{array}{l}\text { End of experiment ( } 33 \\
\text { DAS) }\end{array}$} \\
\hline & ${ }^{33} \mathrm{P}(\mathrm{MBq})$ & ${ }^{31} \mathrm{P}$ (mg P) & ${ }^{33} \mathrm{P}(\mathrm{MBq})$ & ${ }^{31} \mathrm{P}$ (mg P) & ${ }^{33} \mathrm{P}(\mathrm{MBq})$ & ${ }^{31} \mathrm{P}(\mathrm{mg} \mathrm{P})$ & ${ }^{33} \mathrm{P}(\mathrm{MBq})$ & ${ }^{31} \mathrm{P}$ (mg P) \\
\hline Control & $\begin{array}{l}20 \\
(0.3)\end{array}$ & $\begin{array}{l}108 \\
(3)\end{array}$ & $\begin{array}{l}11.5 \\
(1.6)\end{array}$ & $\begin{array}{l}62 \\
(7)\end{array}$ & na & na & na & na \\
\hline$+P$ & $\begin{array}{l}29.4 \\
(1.3)\end{array}$ & $\begin{array}{l}104 \\
(4)\end{array}$ & $\begin{array}{l}18.0 \\
(1.7)\end{array}$ & $\begin{array}{l}51 \\
(6)\end{array}$ & 0 & $\begin{array}{l}104^{a} \\
(3)\end{array}$ & $\begin{array}{l}0.17 \\
(0.08)\end{array}$ & $\begin{array}{l}43 \\
(21)\end{array}$ \\
\hline$-P$ & $\begin{array}{l}29.5 \\
(0.7)\end{array}$ & $\begin{array}{l}104 \\
(3)\end{array}$ & $\begin{array}{l}17.5 \\
(1.0)\end{array}$ & $\begin{array}{l}54 \\
(2)\end{array}$ & 0 & $0^{a}$ & $\begin{array}{l}0.04 \\
(0.006)\end{array}$ & $\begin{array}{l}7 \\
(0.7)\end{array}$ \\
\hline
\end{tabular}

Mean values with $n=3$ for the control and $n=4$ for the $+P$ and $-P$. Values in brackets are the standard deviation

na not applicable

a After 5 days (at 28 DAS) $2 \mathrm{~L}$ nutrient solution was added to the pots of the $+\mathrm{P}$ treatment and $2 \mathrm{~L}$-free nutrient solution was added to the pots of the $-\mathrm{P}$ treatment 
Table 2 Summary of the average dry mass $\left(M_{d}\right)$ for the different compartments and treatments

\begin{tabular}{lccll}
\hline \multicolumn{5}{c}{ Dry mass (g per pot) } \\
\cline { 2 - 5 } & Roots & Stems & Old leaves & New leaves \\
\hline Treatment & & & & \\
Control & $8.1 \mathrm{a}$ & $6.5 \mathrm{a}$ & $4.7 \mathrm{ab}$ & $2.5 \mathrm{a}$ \\
$+\mathrm{P}$ & $16.7 \mathrm{~b}$ & $11.0 \mathrm{~b}$ & $4.8 \mathrm{a}$ & $6.3 \mathrm{~b}$ \\
$-\mathrm{P}$ & $14.3 \mathrm{ab}$ & $13.3 \mathrm{~b}$ & $4.3 \mathrm{~b}$ & $8.7 \mathrm{~b}$ \\
Pooled SD & 4.1 & 1.4 & 0.3 & 1.4 \\
Source of variation $(p$ value) & & & \\
Treatment & 0.07 & $<0.001$ & 0.08 & 0.001 \\
\hline
\end{tabular}

Values are means with $n=3$ for the control and $n=4$ for the $+P$ and $-P$. Letters behind values indicate significant differences between the different treatment within the same plant parts based on a Tukey's HSD test with $a=0.05$. Pooled standard deviation (pooled SD)

was taken up, was recovered in the plants. The proportional distribution of the total activity of ${ }^{33} \mathrm{P}$ among the different compartments is shown in Fig. 2. The proportion of ${ }^{33} \mathrm{P}$ in the TCA $\mathrm{P}$ was higher than in the residual $\mathrm{P}$ (Fig. 2). The highest proportion of ${ }^{33} \mathrm{P}$ was found in the TCA P of the roots and old leaves in the case of the control and in the roots and stems in the case of the $+\mathrm{P}$ and - $\mathrm{P}$ plants (Fig. 2). The proportion of ${ }^{33} \mathrm{P}$ in the residual $\mathrm{P}$ increased significantly from the control and $+P$ plants to the - P plants (ANOVA, $p$ value $<0.001$; Fig. 2 ). Around
$14 \%$ of the ${ }^{33} \mathrm{P}$ was found in the total $\mathrm{P}$ of the unifoliate leaves (UL) in case of all three treatments.

\section{Amount of phosphorus derived from the labelling period and the non-labelling period}

Using Eqs. 3 and 4, the amounts of $\mathrm{P}$ derived from the labelling period and non-labelling period in $\mathrm{mg} \mathrm{P}$ per compartment were calculated (Table 3).

Net gains and losses of $\mathrm{P}$ in the different compartments of the $-\mathrm{P}$ and $+\mathrm{P}$ plants for the period 23-33 DAS were calculated using Eqs. 5 and 6 and are shown in Fig. 3 . The main sinks in the $-\mathrm{P}$ plants for the $\mathrm{P}$ derived from the labelling period was the residual $\mathrm{P}$ of the roots, stems, and new leaves and to a lesser degree also the TCA P pool of the stems and new leaves (Fig. 3). The main sources of $P$ in the $-P$ plants were the TCA and residual $\mathrm{P}$ in the old leaves and the roots from the labelling and non-labelling periods (Fig. 3). In the case of the $+\mathrm{P}$ plants, the higher proportion of $\mathrm{P}$ was derived from the period referred to as "non-labelling period". The main sink for the $\mathrm{P}$ derived from the labelling period in the $+\mathrm{P}$ plants was the residual and TCA P of the new leaves and of the stems (Fig. 3).

\section{$\delta^{18} \mathrm{O}_{\mathrm{P}}$ of TCA $\mathrm{P}$, leaf water $\delta^{18} \mathrm{O}$ and equilibrium}

The $\delta^{18} \mathrm{O}_{\mathrm{P}}$ of TCA $\mathrm{P}$ extracted from the old and new leaves in all three treatments was more positive than

Table 3 Amount of $P$ in the trichloroacetic acid-soluble reactive $P$ (TCA $P$ ) and in the residual $P$ pool derived from the labelling period [15-23 days after seeding (DAS)], from the non-labelling period, and the total amount of TCA $P$ in each compartment

\begin{tabular}{|c|c|c|c|c|c|c|c|c|c|c|c|c|}
\hline & \multicolumn{4}{|c|}{ Labelling period } & \multicolumn{4}{|c|}{ Non-labelling period } & \multicolumn{4}{|c|}{ Sum (0-33 DAS) } \\
\hline & \multicolumn{12}{|c|}{ mg $\mathrm{P}$ per compartment } \\
\hline & Roots & Stems & Old leaves & New leaves & Roots & Stems & Old leaves & New leaves & Roots & Stems & Old leaves & New leaves \\
\hline \multicolumn{13}{|l|}{ TCAP } \\
\hline Control & $17.6 \mathrm{a}$ & $6.7 a$ & $12.5 \mathrm{a}$ & $3.0 \mathrm{a}$ & $6.9 a$ & $4.9 a$ & $5.8 a$ & $0.9 a$ & $24.5 \mathrm{a}$ & $11.6 a$ & $18.3 a$ & $3.9 a$ \\
\hline$+P$ & $10.9 \mathrm{a}$ & $12.0 \mathrm{a}$ & $9.3 a b$ & $6.3 b$ & $36.8 b$ & $26.9 b$ & $9.9 a$ & $17.2 \mathrm{~b}$ & $47.7 b$ & $38.9 b$ & $19.1 \mathrm{a}$ & $23.5 b$ \\
\hline$-P$ & $9.8 a$ & $9.5 \mathrm{a}$ & $3.0 \mathrm{~b}$ & $5.2 \mathrm{ab}$ & $4.0 \mathrm{a}$ & $4.5 \mathrm{a}$ & $0.7 b$ & $2.2 \mathrm{a}$ & $13.8 \mathrm{c}$ & $14.0 \mathrm{a}$ & $3.7 b$ & $7.4 \mathrm{a}$ \\
\hline Pooled SD & 4.6 & 3.3 & 3.7 & 1.4 & 10.6 & 11.1 & 4.3 & 13.5 & 3.9 & 4.2 & 4.0 & 4.2 \\
\hline \multicolumn{13}{|c|}{ Source of variation ( $p$ value) } \\
\hline Treatment & ns & ns & 0.03 & 0.05 & $<0.001$ & $<0.001$ & $<0.001$ & $<0.001$ & $<0.001$ & $<0.001$ & 0.001 & $<0.001$ \\
\hline \multicolumn{13}{|l|}{ Residual P } \\
\hline Control & $1.6 a$ & $0.9 a$ & $1.7 \mathrm{a}$ & $1.0 \mathrm{a}$ & $1.1 \mathrm{a}$ & $0.9 a$ & $1.2 \mathrm{a}$ & $0.5 a$ & $2.6 a$ & $1.8 \mathrm{a}$ & $2.9 a$ & $1.5 \mathrm{a}$ \\
\hline$+P$ & $1.5 \mathrm{a}$ & $2.5 b$ & $1.4 \mathrm{a}$ & $2.5 \mathrm{a}$ & $3.8 b$ & $5.1 \mathrm{~b}$ & $2.8 \mathrm{a}$ & $4.4 b$ & $5.3 b$ & $7.7 b$ & $4.2 \mathrm{a}$ & $6.8 b$ \\
\hline$-P$ & $2.4 \mathrm{a}$ & $4.7 c$ & $1.5 \mathrm{a}$ & $6.9 b$ & $1.2 \mathrm{a}$ & $0.6 a$ & $0.5 a$ & $1.6 a b$ & $3.6 a$ & $5.2 \mathrm{~b}$ & $2.0 \mathrm{a}$ & $8.5 b$ \\
\hline Pooled SD & 0.6 & 0.3 & 0.2 & 0.5 & 0.9 & 0.9 & 1.9 & 3.0 & 1.4 & 1.0 & 1.4 & 2.1 \\
\hline \multicolumn{13}{|c|}{ Source of variation ( $p$ value) } \\
\hline Treatment & ns & $<0.001$ & ns & $<0.001$ & 0.006 & $<0.001$ & ns & 0.05 & 0.1 & $<0.001$ & ns & 0.006 \\
\hline
\end{tabular}

In the case of the control, the non-labelling period includes the first 15 days (0-15 DAS). In the case of the $+\mathrm{P}$ and $-\mathrm{P}$, the non-labelling period represents the time from 0 to 15 DAS and from 23 to 33 DAS. Letters behind values indicate significant differences between the treatments within the same plant part based on a Tukey's HSD test with $a=0.05$ 


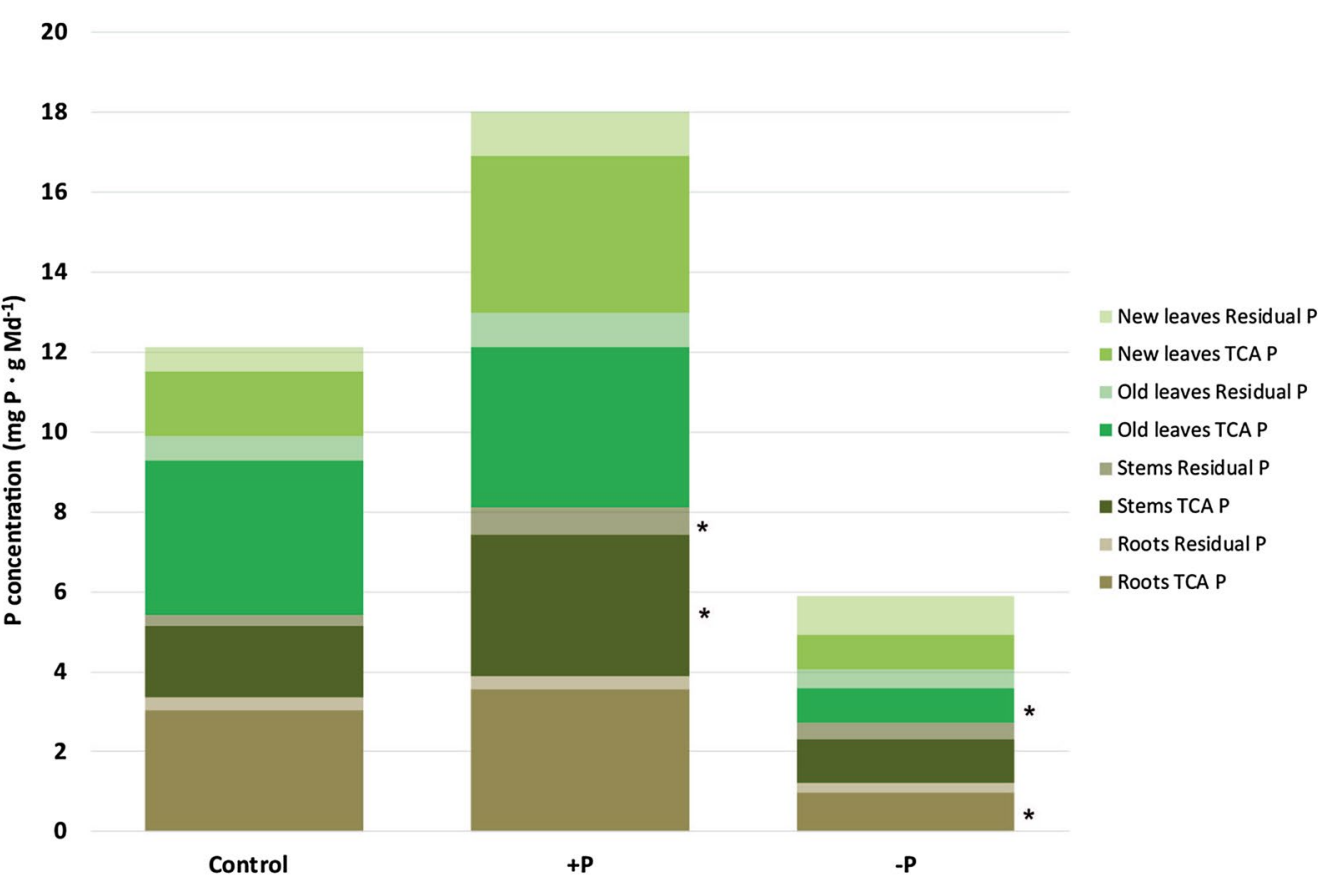

Fig. 1 Phosphorus concentration (mg P per g dry mass) in the two different P pools [trichloroacetic acid soluble-reactive P (TCA P) and residual $P$ ] and four different plant parts for the control, $+P$, and $-P$ plants. Error bars are $\pm S D$ with $n=3$ for the control and $n=4$ for the $+P$ and $-P$. Significant differences between treatments within the same plant part are indicated by asterisks; Tukey's HSD test with $a=0.05$

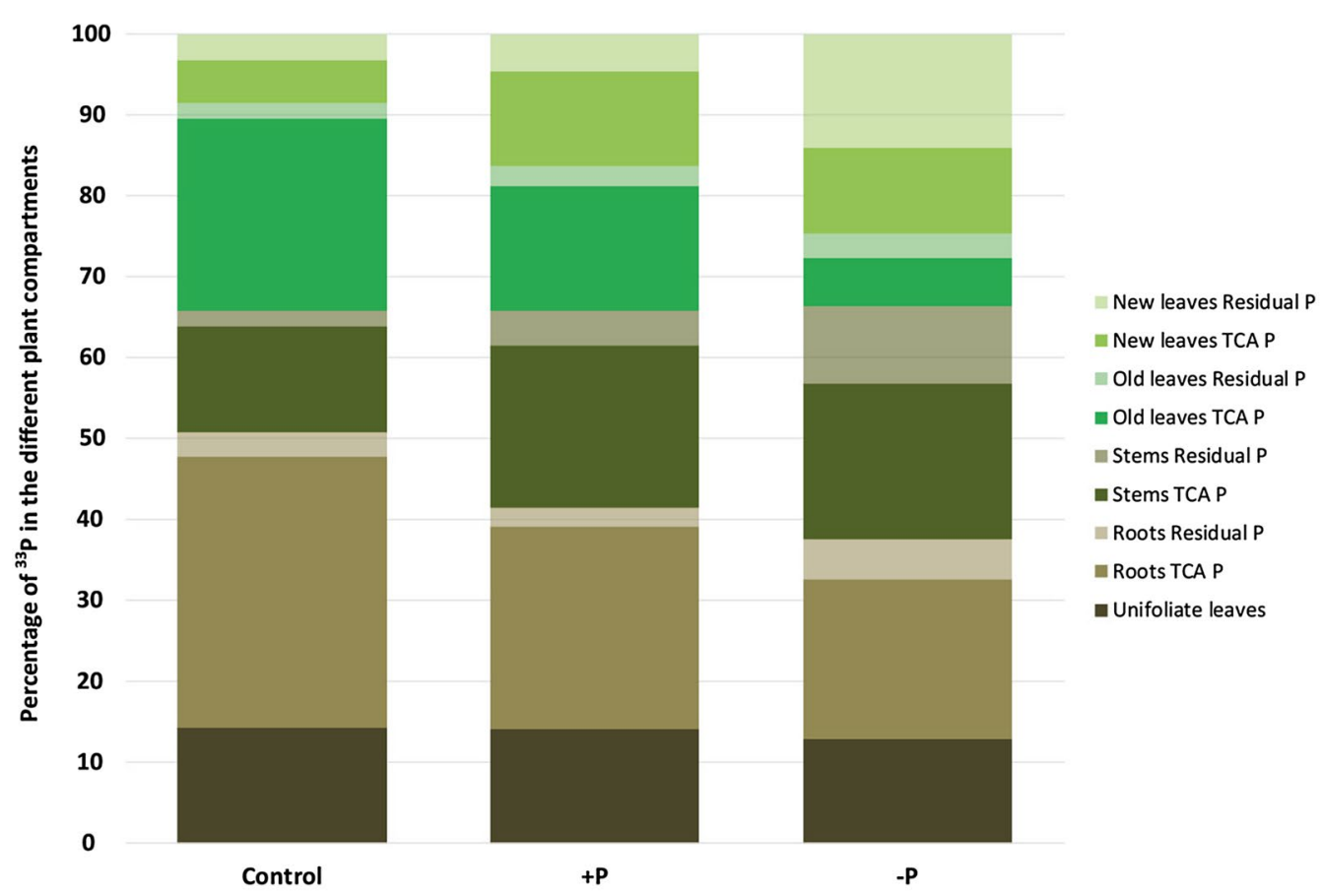

Fig. 2 Proportion of ${ }^{33} \mathrm{P}$ in the different plant compartments for the control, $+\mathrm{P}$, and - P. $100 \%$ is equivalent to $9.5 \mathrm{MBq}, 12.4 \mathrm{MBq}$, and $11.9 \mathrm{MBq}$ in the case of the control, $+P$, and - P plants, respectively 


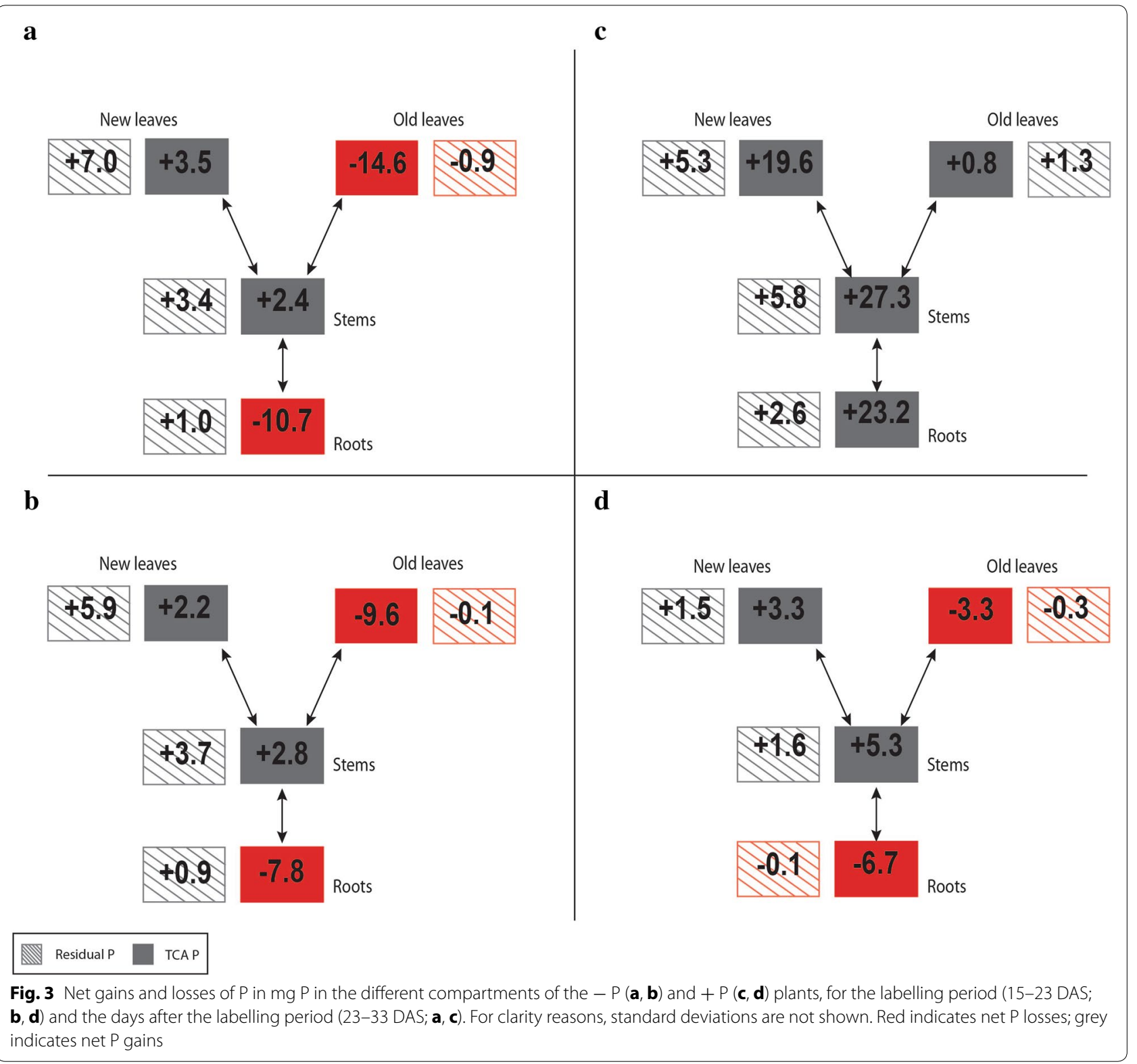

the phosphate source $(12.4 \%$; Table 4$)$, whereas in the roots and stems it was like that of the phosphate source (Table 4). Significant differences were observed between the $\delta^{18} \mathrm{O}_{\mathrm{P}}$ of TCA P in the old leaves of the control, $+\mathrm{P}$ and $-\mathrm{P}$ plants and in the new leaves between the control and $-\mathrm{P}$ plants and between the $+\mathrm{P}$ and $-\mathrm{P}$ plants.

Based on Eq. 7 the estimated leaf water $\delta^{18} \mathrm{O}$ at a relative air humidity of $58 \%$ is between 7.3 and $7.7 \%$ in case of the old leaves (leaf temperature range $19-22{ }^{\circ} \mathrm{C}$ ) and between 7.4 and $7.9 \%$ in case of the new leaves (leaf temperature $20-24{ }^{\circ} \mathrm{C}$ ). Using these values and the measured leaf temperatures, equilibrium calculated with Eq. 8 is between 29.7 and $30.6 \%$ for the old leaves and between 29.6 and $30.7 \%$ for the new leaves. The water $\delta^{18} \mathrm{O}$ in roots and stems is usually close to the source water $\delta^{18} \mathrm{O}(-10.2 \%$ in this study). Thus, using a temperature range of $18-22{ }^{\circ} \mathrm{C}$, the equilibrium for stems and roots is between 12.3 and $12.9 \%$.

\section{Discussion}

Omitting $\mathrm{P}$ in the nutrient solution did not affect the dry mass of our soybean plants and - P plants did not show visible signs of $\mathrm{P}$ limitation like darker leaves or stunted growth. This is most likely due to the high $(0.5 \mathrm{mM} \mathrm{P})$ amount of $\mathrm{P}$ supplied in the nutrient solution and the short duration of the $\mathrm{P}$ omission (10 days). Indeed, Fredeen et al. [36] observed visible signs of $P$ limitation in soybeans grown in low $\mathrm{P}(0.01 \mathrm{mM} \mathrm{P})$ nutrient solution 
Table $4 \delta^{18} O_{p}$ of trichloroacetic acid-soluble reactive $P$ (TCA P) of the four different parts (roots, stems, old and new leaves) of the plants for the three different treatments (control, + P and - P)

\begin{tabular}{|c|c|c|c|c|}
\hline & \multicolumn{4}{|c|}{$\delta^{18} O_{p}(\% o)$} \\
\hline & Roots & Stems & Old leaves & New leaves \\
\hline \multicolumn{5}{|l|}{ Treatments } \\
\hline Control & 12.0a, A & 14.9a, B & $29.8 a, C$ & $25.9 a, D$ \\
\hline$+P$ & $11.5 \mathrm{a}, \mathrm{A}$ & $13.5 a, B$ & $27.4 b, C$ & 25.7a, D \\
\hline$-P$ & 12.0a, A & 13.9a, B & $23.8 c, C$ & $24.2 b, c$ \\
\hline Pooled SD & 0.7 & 1.1 & 0.9 & 0.7 \\
\hline \multicolumn{5}{|c|}{ Source of variation ( $p$ value) } \\
\hline Treatment & ns & ns & $<0.001$ & 0.02 \\
\hline
\end{tabular}

Values are means with $n=3$ for the control and $n=4$ for the $+P$ and $-P$ plants. Small letters indicate significant differences between treatments within the same plant part; capital letters indicate significant differences between plant parts within the same treatment (Tukey's HSD; $a=0.05$ ). Pooled standard deviation (pooled SD)

ns not significant

from the beginning of the experiment only after 10 days. Nevertheless, we observed changes in the distribution of $\mathrm{P}$ in the different plant parts and $\mathrm{P}$ pools, which indicates a change in plant metabolism.

\section{Plant water $\delta^{18} \mathrm{O}$ and the $\delta^{18} \mathrm{O}_{\mathrm{p}}$ of TCA $\mathrm{P}$}

The $\delta^{18} \mathrm{O}_{\mathrm{P}}$ of TCA P of the old leaves of the control plants and of the stems and roots in general were relatively close to the calculated equilibrium with the plant water [Table 3; 29.7-30.6\%o (equilibrium range old leaves), 12.3-12.9\%o (equilibrium range stems and roots)]. Differences between calculated equilibrium and measured $\delta^{18} \mathrm{O}_{\mathrm{P}}$ of TCA $\mathrm{P}$ values are not caused by the leaf water $\delta^{18} \mathrm{O}$, even though the equilibrium values are calculated using several assumptions. The $+\mathrm{P}$ and $-\mathrm{P}$ plants were harvested within half an hour and thus the leaf water $\delta^{18} \mathrm{O}$ should not vary greatly [26]. Furthermore, the variability of the $\delta^{18} \mathrm{O}_{\mathrm{P}}$ of TCA P among the four replicates per treatment was low, indicating that the sampling time ( $<30 \mathrm{~min}$ ) did not affect the $\delta^{18} \mathrm{O}_{\mathrm{P}}$ of TCA P. In addition, we consider that transpiration, the main driver behind changes in the leaf water $\delta^{18} \mathrm{O}$, of the $+\mathrm{P}$ and $-\mathrm{P}$ plants was the same, as $+\mathrm{P}$ and $-\mathrm{P}$ plants did not differ in their water uptake and biomass. Based on Eq. 8 the difference in leaf water $\delta^{18} \mathrm{O}$ between old and new leaves would be rather small and we thus assume that leaf water $\delta^{18} \mathrm{O}$ values are not the cause for lower $\delta^{18} \mathrm{O}_{\mathrm{P}}$ of TCA P values of the new leaves compared to the old leaves.

\section{Changes in the $\delta^{18} \mathrm{O}_{\mathrm{p}}$ of TCA P and the distribution of ${ }^{33} \mathrm{P}$}

The amount of $\mathrm{P}$ and distribution of ${ }^{33} \mathrm{P}$ within the plants indicate that $\mathrm{P}$ was mobilised and translocated between different plant parts in the $-\mathrm{P}$ and $+\mathrm{P}$ soybean plants in our study (Table 3 and Fig. 3). This is not surprising as $\mathrm{P}$ is continuously circulated between plant parts even when plants are not P limited as shown by [37]. In line with this, the translocated $\mathrm{P}$, derived from the labelling period was mainly found in the TCA P of the new leaves and stems (Fig. 3). In case of the $-\mathrm{P}$ plants, the omission of $P$ resulted in an enhanced re-mobilisation of $P$ from residual $\mathrm{P}$ in the old leaves and translocation of $\mathrm{P}$ from the TCA P in the old leaves and roots to the new leaves and stems (TCA and residual P; Fig. 3). Mobilisation and translocation of $\mathrm{P}$ is a common response of plants to the omission of $\mathrm{P}$ and was observed for a wide range of plant species (for example soybean, mashbean and mungbean [38], citrus trees [39], beans [40], Brachiaria [41], and peas [42]). Except for the residual $\mathrm{P}$ in the old leaves, $\mathrm{P}$ derived from the labelling period, was translocated and used for the synthesis of residual $\mathrm{P}$ in the roots, stems, and new leaves. There was a small efflux of $P$, which had been taken up during the labelling period, to the nutrient solution in the last 10 days of the experiment for both $+\mathrm{P}$ and $-\mathrm{P}$ plants (Table 1). An increased efflux of $\mathrm{P}$ has been observed for plants grown at high $\mathrm{P}$ levels [43]. This could help the plant to maintain $P$ homeostasis and possibly explain the efflux in case of the $+\mathrm{P}$ plants. The efflux of ${ }^{33} \mathrm{P}$ could also have been caused by senescent root tissue entering the nutrient solution, which was most likely the case for the $-\mathrm{P}$ plants.

Re-mobilisation of residual P, i.e. organic P, as observed for example the old leaves of the $-\mathrm{P}$ plants, involves hydrolysing enzymes such as acid phosphatase [44-46]. A discrimination factor of $-10 \%$ was reported for acid phosphatase, leading to a depletion in ${ }^{18} \mathrm{O}$ of the released phosphate [22]. To estimate the $\delta^{18} \mathrm{O}$ of phosphate released by hydrolysing enzymes, we would need to know the $\delta^{18} \mathrm{O}$ of residual $\mathrm{P}$ (organic compounds) inside the plants. At present, we can only approximate this value by considering that organic compounds in a cell have the same $\delta^{18} \mathrm{O}_{\mathrm{P}}$ as phosphate inside the cell [47]. If we assume a $\delta^{18} \mathrm{O}_{\mathrm{P}}$ of residual $\mathrm{P}$ of $27.4 \% 0\left(\delta^{18} \mathrm{O}_{\mathrm{P}}\right.$ of TCA P in the old leaves of the $+\mathrm{P}$ plants) and a leaf water $\delta^{18} \mathrm{O}$ values between 7.2 and $7.5 \%$, phosphate released due the hydrolysis of residual $P$ by acid phosphatase would have a $\delta^{18} \mathrm{O}_{\mathrm{P}}$ value around $20 \%$. The release of such light phosphate could explain our observed differences in the $\delta^{18} \mathrm{O}_{\mathrm{P}}$ of TCA P of $+\mathrm{P}$ and $-\mathrm{P}$ plants as shown with the following calculations and considerations.

We observed a net $\mathrm{P}$ loss of $0.9 \mathrm{mg} \mathrm{P}$ from residual $\mathrm{P}$ in the old leaves of the $-\mathrm{P}$ plants during the last 10 days of the experiment (Fig. 3). The total amount of TCA P in the old leaves was $3.7 \mathrm{mg}$ (Table 3). Thus, P mobilised from residual $P$ in the old leaves could potentially make up $25 \%$ of the TCA P in the old leaves of the - P plants. Using a simple mass balance, the $\delta^{18} \mathrm{O}_{\mathrm{P}}$ of TCA P in the old leaves 
of the $-\mathrm{P}$ plants would be around $25.5 \%$. Such a mixing could also explain the lower $\delta^{18} \mathrm{O}_{\mathrm{P}}$ of TCA P in the new leaves of the $-\mathrm{P}$ plants compared to the $+\mathrm{P}$ plants. Light phosphate produced by phosphatases in developed leaves could be transported to developing leaves, diluting the TCA P pool and leading to lower $\delta^{18} \mathrm{O}_{\mathrm{P}}$ values.

As phosphate is transported from the old leaves to the new leaves via the stems, such a mixing could also explain the slightly, but not significantly, lower $\delta^{18} \mathrm{O}_{\mathrm{P}}$ of TCA $\mathrm{P}$ values of the stems in case of the $+\mathrm{P}$ and $-\mathrm{P}$ plants compared to the control plants. Doing a similar calculation for the stems of the - P plants as for the old leaves of the $-\mathrm{P}$ plants, $18 \%$ of the TCA P in the stems would be $\mathrm{P}$ originating from the hydrolysis of residual $\mathrm{P}$ based on $\delta^{18} \mathrm{O}_{\mathrm{p}}$ values and by $17 \%$ based on Fig. 3 and Table 3.

The stems of the $+\mathrm{P}$ plants present a more complicated case, since $\mathrm{P}$ continues to be taken up from the nutrient solution. Phosphorus in the stems increased by $70 \%$ (Fig. 3 and Table 3). Using the $\delta^{18} \mathrm{O}_{\mathrm{p}}$ of TCA P, only $7 \%$ would originated from $\mathrm{P}$ released by hydrolysis, whereas $63 \%$ would be $\mathrm{P}$ taken up from the nutrient solution. $7 \%$ of the amount of TCA P in the stems is $2.7 \mathrm{mg}$ and are very close to the amount of residual $\mathrm{P}$ mobilised from the old leaves $(3.3 \mathrm{mg})$. It is possible that changes of the $\delta^{18} \mathrm{O}_{\mathrm{P}}$ of TCA P in the stems of the $+\mathrm{P}$ and $-\mathrm{P}$ plants compared to the control plants reflect a mixing of different phosphate sources.

Translocation of $P$ from the TCA P was also observed in case of the roots $(+\mathrm{P}$ and $-\mathrm{P}$ plants; Fig. 3$)$, but contrary to the $\delta^{18} \mathrm{O}_{\mathrm{p}}$ of TCA P in the old leaves, the $\delta^{18} \mathrm{O}_{\mathrm{P}}$ of TCA P in the roots did not change from the $+\mathrm{P}$ to the $-\mathrm{P}$ plants. Unlike in the old leaves, no net loss of $\mathrm{P}$ from the residual $\mathrm{P}$ in the roots during the last 10 days of the experiment was observed. Thus, contribution of phosphate released from residual $\mathrm{P}$ by hydrolysing enzymes to the TCA P pool in the roots was negligible. In the case of the $+\mathrm{P}$ plants also the high $\mathrm{P}$ influx from the nutrient solution and the high amount of TCA P in the roots might have masked any contribution of $\mathrm{P}$ with a lighter $\delta^{18} \mathrm{O}_{\mathrm{P}}$ value.

The $\delta^{18} \mathrm{O}_{\mathrm{P}}$ of TCA P in the roots, as well as in the stems of the $-P$ plants was close to the calculated equilibrium as well as to the $\delta^{18} \mathrm{O}_{\mathrm{P}}$ of the $\mathrm{P}$ source in the nutrient solution $(12.4 \%)$. However, the $-\mathrm{P}$ plants did not receive any $P$ for the last 10 days of the experiment and most of the TCA P in the roots was translocated to other compartments (Fig. 3). This strongly suggests that in the roots and stems, the $\delta^{18} \mathrm{O}_{\mathrm{p}}$ signature of the $\mathrm{P}$ source is reset by $\mathrm{O}$ exchange with water mediated by inorganic PPase and other acid anhydride hydrolases $[18,20]$. Acid anhydride hydrolases are also present in stems and roots [48], as they are important for loading and unloading of the xylem and phloem in the roots and stem [49-52].

\section{Conclusions}

By using a dual isotopic approach $\left({ }^{33} \mathrm{P}\right.$ and the $\left.\delta^{18} \mathrm{O}_{\mathrm{P}}\right)$ we simultaneously investigated $\mathrm{P}$ translocation and the enzymatic release of $\mathrm{P}$ due to a change in $\mathrm{P}$ nutrition. We showed that stopping $\mathrm{P}$ supply for 10 days lead to a translocation of $\mathrm{P}$ from source organs, mainly from residual $\mathrm{P}$, to sink organs of up to $25 \%$. Furthermore, the $\delta^{18} \mathrm{O}_{\mathrm{P}}$ of TCA P in source organs was significantly lower compared to sink organs due to the enzymatic hydrolysis of organic P. Through further studies with different plant species, the $\delta^{18} \mathrm{O}_{\mathrm{P}}$ can become a useful tool to investigate early responses of plants to $\mathrm{P}$ limitation-in field and laboratory studies-before any visible signs of $\mathrm{P}$ limitation are observed. This requires also that more fractionation factors associated with enzymes involved in P mobilisation and translocation in plants are characterised, as well as a method to determine the $\delta^{18} \mathrm{O}_{\mathrm{p}}$ of organic P in plants.

\section{Abbreviations}

ANOVA: analysis of variance; APM: ammonium phospho-molybdate; DAS: days after seeding; $\mathrm{dd}_{2} \mathrm{O}$ : ultra-pure water; $\delta^{18} \mathrm{O}$ : isotopic composition of oxygen; $\delta^{18} \mathrm{O}_{\mathrm{p}}$ : isotopic composition of oxygen associated to phosphorus; GB: gas bench; GISP: Greenland ice sheet precipitation; He: helium; IAEA: International Atomic Energy Agency; IRMS: isotope ratio mass spectrometer; $M_{\mathrm{d}}$ : dry mass; O: oxygen; P: phosphorus; - P: no P supplied for 10 days; + P: sufficient amount of $P$ supplied throughout the experiment; PPase: pyrophosphatase; ${ }^{33} \mathrm{P}_{-} \mathrm{PO}_{4}:{ }^{33} \mathrm{P}$ labelled phosphate; $\mathrm{P}_{\text {tot }}$ : total $\mathrm{P}$; $\mathrm{R}$ : isotopic ratio of ${ }^{18} \mathrm{O}$ to ${ }^{16} \mathrm{O}$; Residual P: P extracted by $10 \mathrm{M} \mathrm{HNO}_{3}$ after extraction with TCA; Residual ${ }^{33} \mathrm{P}$ : activity of ${ }^{33} \mathrm{P}$ in the residual $\mathrm{P}$; $\mathrm{rH}$ : relative humidity; $\mathrm{SA}$ : specific activity; $S A_{\text {nut }}$ sol: specific activity in the nutrient solution; SLAP: standard light Antarctic precipitation; TCA: trichloroacetic acid; TCA P: trichloroacetic acid soluble reactive phosphorus; TCA ${ }^{33} \mathrm{P}$ : activity of ${ }^{33} \mathrm{P}$ in TCA P; TC/EA: thermal conversion elemental analyser; $T_{\text {leaf: }}$ leaf temperature; UL: unifoliate leaves; VSMOW: Vienna standard mean ocean water; $x$ : amount of $P$ derived from the labelling period; $x_{\text {control }}$ : amount of $\mathrm{P}$ taken up during the labelling period in the control plants; $x_{i}$ : amount of $P$ taken up during the labelling period in the $+\mathrm{P}$ or $-\mathrm{P}$ plants; $y$ : activity of ${ }^{33} P$ in a certain compartment; $z$ : amount of $P$ derived from before and after the labelling period; $z_{\text {control }}$ : amount of $P$ derived from before the labelling period in the control plants; $z_{i}$ : amount of $P$ derived from before and after labelling period in the + P or - P plants.

\section{Authors' contributions}

VP conducted the research and analysed the data. VP, FT, SMB, and EF were involved in the planning of the experiment. All authors contributed to the manuscript. All authors read and approved the final manuscript.

\section{Author details}

${ }^{1}$ Department of Environmental Systems Science, ETH Zurich, Eschikon 33, 8315 Lindau, Switzerland. ${ }^{2}$ Sustainable Agriculture Sciences, Rothamsted Research, Okehampton, Devon EX20 2SB, UK. ${ }^{3}$ Department of Earth Sciences, ETH Zurich, Sonneggstrasse 5, 8001 Zurich, Switzerland.

\section{Acknowledgements}

The authors would like to thank the research commission of the ETH Zurich for funding this project (Grant Number: ETH-02_10-2) and Delley seeds and plants Ltd (Delley, Switzerland) for providing the soybean seeds. We would also like to thank B. Aciksöz and L. Schönholzer with their help during the experiment. We thank an anonymous reviewer for the helpful comments. 


\section{Competing interests}

The authors declare that they have no competing interests.

\section{Availability of data and materials}

Not applicable.

\section{Consent for publication}

Not applicable.

Ethics approval and consent to participate

Not applicable.

\section{Funding}

Research commission ETH Zurich, Grant Number ETH-02_10-2.

\section{Publisher's Note}

Springer Nature remains neutral with regard to jurisdictional claims in published maps and institutional affiliations.

Received: 20 April 2017 Accepted: 17 September 2017

Published online: 25 September 2017

\section{References}

1. Mimura T, Sakano K, Shimmen T. Studies on the distribution, re-translocation and homeostasis of inorganic phosphate in barley leaves. Plant, Cell Environ. 1996;19:311-20.

2. Schachtman DP, Reid RJ, Ayling SM. Phosphorus uptake by plants: from soil to cell. Plant Physiol. 1998;1 16(2):447-53.

3. Bieleski RL. Phosphate pools, phosphate transport, and phosphate availability. Annual Review of Plant Physiology. 1973;24:225-52.

4. Bieleski RL, Ferguson IB. Physiology and metabolism of phosphate and its compounds. In: Läuchli A, Bieleski RL, editors. Inorganic plant nutrition, vol. 15. Berlin: Springer; 1983. p. 422-49.

5. Mimura T. Homeostasis and transport of inorganic-phosphate in plants. Plant Cell Physiol. 1995:36(1):1-7.

6. Rebeille F, Bligny R, Martin JB, Douce R. Relationship between the cytoplasm and the vacuole phosphate pool in Acer pseudoplatanus cells. Arch Biochem Biophys. 1983;225(1):143-8.

7. Duff SMG, Sarath G, Plaxton WC. The role of acid phosphatases in plant phosphorus metabolism. Physiol Plant. 1994;90:791-800.

8. Tjellström H, Andersson MX, Larsson KE, Sandlius AS. Membrane phospholipids as a phosphate reserve: the dynamic nature of phospholipidto-digalactosyl diacylglycerol exchange in higher plants. Plant, Cell Environ. 2008:31:1388-98.

9. Shen J, Yuan L, Zhang J, Li H, Bai Z, Chen X, Zhang W, Zhang F. Phosphorus dynamics: from soil to plant. Plant Physiol. 2011;156(3):997-1005.

10. Lambers H, Cawthray GR, Giavalisco P, Kuo J, Laliberte E, Pearse SJ, Scheible WR, Stitt M, Teste F, Turner BL. Proteaceae from severely phosphorusimpoverished soils extensively replace phospholipids with galactolipids and sulfolipids during leaf development to achieve a high photosynthetic phosphorus-use-efficiency. New Phytol. 2012;196(4):1098-108.

11. Veneklaas EJ, Lambers H, Bragg J, Finnegan PM, Lovelock CE, Plaxton WC, Price CA, Scheible W-R, Shane MW, White PJ, et al. Opportunities for improving phosphorus-use efficiency in crop plants. New Phytol. 2012;195(2):306-20.

12. Bieleski RL. Turnover of phospholipids in normal and phosphorus-deficient Spirodela. Plant Physiol. 1972;49(5):740-5.

13. Kanno S, Tanoi K, Nakanishi TM. Real-time imaging of ${ }^{32} \mathrm{P}$ translocation in soybean plants. Radioisotopes. 2009;58:743-7.

14. Blake RE, O'Neil JR, Garcia GA. Oxygen isotope systematics of biologically mediated reactions of phosphate: I. Microbial degradation of organophosphorus compounds. Geochim Cosmochim Acta. 1997;61(20):4411-22.

15. Blake RE, O'Neil JR, Surkov AV. Biogeochemical cycling of phosphorus: insights from oxygen isotope effects of phosphoenzymes. Am J Sci. 2005:305:596-620.
16. Liang Y, Blake RE. Compound- and enzyme-specific phosphodiester hydrolysis mechanisms revealed by $\delta^{18} \mathrm{O}$ of dissolved inorganic phosphate: implications for marine P cycling. Geochim Cosmochim Acta. 2009;73:3782-94.

17. Chang SJ, Blake RE. Precise calibration of equilibrium oxygen isotope fractionations between dissolved phosphate and water from 3 to $37^{\circ} \mathrm{C}$ Geochim Cosmochim Acta. 2015;150:314-29.

18. Cohn M. Posphate-water exchange reaction catalyzed by inorganic pyrophosphatase of yeast. J Biol Chem. 1958;230(1):369-80.

19. Hirata T, Nakamura N, Omote H, Wada Y, Futai M. Regulation and reversibility of vacuolar $\mathrm{H}^{+}$-ATPase. J Biol Chem. 2000;275(1):386-9.

20. Boyer PD. A research journey with ATP synthase. J Biol Chem. 2002;277(42):39045-61.

21. Liang Y, Blake RE. Oxygen isotope signature of Pi regeneration from organic compounds by phosphomonoesterases and photooxidation. Geochim Cosmochim Acta. 2006:70(15):3957-69.

22. von Sperber C, Kries H, Tamburini F, Bernasconi SM, Frossard E. The effect of phosphomonoesterases on the oxygen isotope composition of phosphate. Geochim Cosmochim Acta. 2014;125:519-27.

23. Pfahler $V$, Durr-Auster T, Tamburini F, Bernasconi SM, Frossard E. ${ }^{18} \mathrm{O}$ enrichment in phosphorus pools extracted from soybean leaves. New Phytol. 2013;197(1):186-93.

24. Kremer RJ, Means NE, Kim S. Glyphosphate affects soybean root exudation and rhizosphere micro-organisms. Int J Environ Anal Chem. 2005;85(15):1165-74

25. Fehr WR, Caviness CE, Burmood DT, Pennington JS. Stage of development descriptions for soybeans, Glycine Max (L.) Merrill. Crop Sci. 1971;11:929-31.

26. Pfahler V. Factors controlling the isotopic composition of oxygen bound to phosphorus in glycine max. Switzerland: ETH Zurich; 2014

27. Barbour MM, Cernusak LA, Farquhar GD. Factors affecting the oxygen isotope ratio of plant organic material. In: Flanagan LB, Ehleringer JR, Pataki DE, editors. Stable isotopes and biosphere atmosphere interactions. San Diego: Academic Press; 2005. p. 9-28.

28. Hawkins B, Polglase PJ. Foliar concentrations and resorption of nitrogen and phosphorus in 15 species of eucalypts grown under non-limited water and nutrient availability. Aust J Bot. 2000;48:597-602.

29. Broberg O, Pettersson K. Analytical determination of orthophosphate in water. Hydrobiologia. 1988;170(1):45-59.

30. Tudge AP. A method of analysis of oxygen isotopes in orthophosphateits use in the measurement of paleotemperatures. Geochim Cosmochim Acta. 1960;18(1-2):81-93.

31. Van Veldhoven PP, Mannaerts GP. Inorganic and organic phosphate measurements in the nanomolar range. Anal Biochem. 1987;161(1):45-8.

32. Tamburini F, Bernasconi SM, Angert A, Frossard E. A method for the analysis of the $\delta^{18} \mathrm{O}$ of inorganic phosphate in soils extracted with $\mathrm{HCl}$. Eur J Soil Sci. 2010;61(6):1025-32

33. Epstein $\mathrm{S}$, Mayeda T. Variation of $\mathrm{O}^{18}$ content of waters from natural sources. Geochim Cosmochim Acta. 1953:4(5):213-24.

34. Tamburini F, Bernasconi SM, Paytan A. Phosphorus in the environment. Eos, Transactions American Geophysical Union. 2012;93(41):405.

35. R Core Team. R: a language and environment for statistical computing. Vienna: R Core Team; 2012.

36. Fredeen AL, Rao IM, Terry N. Influence of phosphorus nutrition on growth and carbon partitioning in Glycine max. Plant Physiol. 1989;89(1):225-30

37. Biddulph O, Biddulph S, Cory R, Koontz H. Circulation patterns for phosphorus, sulfur and calcium in the bean plant. Plant Physiol. 1958;33:293-300.

38. Chaudhary MI, Adu-Gyamfi JJ, Saneoka H, Nguyen NT, Suwa R, Kanai S, El-Shemy HA, Lightfoot DA, Fujita K. The effect of phosphorus deficiency on nutrient uptake, nitrogen fixation and photosynthetic rate in mashbean, mungbean and soybean. Acta Physiol Plant. 2008:30(4):537-44

39. Zambrosi FCB, Mattos D, Boaretto RM, Quaggio JA, Muraoka T, Syvertsen IP. Contribution of phosphorus $\left({ }^{32} \mathrm{P}\right)$ absorption and remobilization for citrus growth. Plant Soil. 2012;355(1-2):353-62.

40. Kondracka A, Rychter AM. The role of Pi recycling processes during photosynthesis in phosphate-deficient bean plants. J Exp Bot. 1997:48(2):1461-8. 
41. Nanamori M, Shinano T, Wasaki J, Yamamura T, Rao IM, Osaki M. Low phosphorus tolerance mechanisms: phosphorus recycling and photosynthate partitioning in the tropical forage grass, Brachiaria hybrid cultivar mulato compared with rice. Plant Cell Physiol. 2004;45(4):460-9.

42. Tsvetkova GE, Georgiev Gl. Changes in phosphate fractions extracted from different organs of phosphorus starved nitrogen fixing pea plants. J Plant Nutr. 2007;30(10-12):2129-40.

43. Raghothama KG, Karthikeyan AS. Phosphate acquisition. Plant Soil. 2005;274(1-2):37-49.

44. Raposo RWC, Muraoka T, Basso LC, Lavres J, Franzini VI. Acid phosphatase activity and leaf phosphorus content in soybean cultivars. Scientia Agricola. 2004;61(4):439-45.

45. Besford RT. Nutrient imbalances in tomato plants and acid phosphatase activity in the leaves. J Sci Food Agric. 1979;30(3):275-80.

46. Besford RT. Phosphorus nutrition and acid phosphatase activity in the leaves of seven plant species. J Sci Food Agric. 1979;30:281-5.
47. Li H, Yu C, Wang F, Chang SJ, Yao J, Blake RE. Probing the metabolic water contribution to intracellular water using oxygen isotope ratios of $\mathrm{PO}_{4}$. Proc Natl Acad Sci. 2016;113(21):5862-7.

48. Wang $Y$, Leigh $\mathrm{RA}$, Kaestner $\mathrm{KH}$, Sze $\mathrm{H}$. Electrogenic $\mathrm{H}^{+}$-pumping pyrophosphatase in tonoplast vesicles of oat roots. Plant Physiol. 1986;81(2):497-502.

49. Raghothama KG. Phosphate transport and signaling. Curr Opin Plant Biol. 2000;3:182-7.

50. Bucher M. Functional biology of plant phosphate uptake at root and mycorrhiza interfaces. New Phytol. 2007;173:11-26.

51. Rausch C, Bucher M. Molecular mechanisms of phosphate transport in plants. Planta. 2002;216:23-37.

52. Lalonde S, Tegeder M, Throne-Holst M, Frommer WB, Patrick JW. Phloem loading and unloading of sugars and amino acids. Plant, Cell Environ. 2003;26(1):37-56

\section{Submit your next manuscript to BioMed Central and we will help you at every step:}

- We accept pre-submission inquiries

- Our selector tool helps you to find the most relevant journal

- We provide round the clock customer support

- Convenient online submission

- Thorough peer review

- Inclusion in PubMed and all major indexing services

- Maximum visibility for your research

Submit your manuscript at www.biomedcentral com/submit 